\title{
Bureaucracy Accountability in Public Administration at Creative Economy and Tourism Department of Makassar in Indonesia
}

\author{
Abdul Sahid \\ Rakhmat \\ Andi Ima Kesuma \\ Department of Public Administration, Universitas Negeri Makassar, Jln. Bonto Langkasa Kampus Gunung Sari Baru, Makassar \\ South Sulawesi; sahidsarome@gmail.com, makmur_stia@gmail.com, a.imakesuma@gmail.com
}

\author{
Doi:10.5901/mjss.2016.v7n5p343
}

\section{Abstract}

This study aimed at determining and analyzing the determinant factors that affected the implementation of bureaucratic accountability in public administration at creative economy and tourism department of Makassar. This study applied a qualitative method with phenomenological approach. The data were collected through observation, interviews, documents, online data searches and FGD. Data sources of the research informants namely Secretary at the tourism department, the head of tourism business development division, head of promotion and tourism marketing division, head of human resources development and public participation division, tour guides, members of PHRI Makassar, staffs of cultural heritage, tour and travel agents and academic. While, the data analysis was qualitative analysis through interactive model of Miles and Huberman (2009). The research result showed that accountable public administration must be supported by professional human resources, high public trust, and good cooperation with other parties. It must be also supported by adequate facilities based on needs and competitive travel.

Keywords: Accountability, administration, Tourism, Professional, Trust, Cooperation, Facility.

\section{Introduction}

Accountability is a measure to show whether or not the public bureaucracy or administration from government was suitable with the values and norms in society. Then, accountability is to measure whether or not the public administration could accommodate what people need. Thus, accountability is related to a philosophy that the government institution (executive) must be responsible to serve people directly or indirectly. In other words, Starling said that accountability is a willingness to answer the questions from public, namely:

A good synonym for the term of accountability is answerability. An organization must be answerable to someone or something outside itself. When things go wrong, someone must be held responsibility. Unfortunately, a frequently heard charge is that government is faceless and that, consequently, affixing blame is difficult.

A commitment is necessary from all parties both from government or society, so good governance could be created. The government must give good service to people based on their needs and expectations. Tourism is an industry with important role in economy activity (Hendrie, 2000). Based on the data from World Travel and Tourism Council (WTTC), tourism is the biggest industry around the world, because the tourism activity can activate the democratic economy activity. Thus it is necessary to be developed in a society empowerment strategy through Community Based Tourism Development.

A tourism project is an integral part from local project to improve the people prosperity, to create a business opportunity, to improve labors and to give contribution for country income by touring. Makassar as the capital of South Sulawesi province is an accumulated place from various ethnics with different customs, characters, art and culture, and tourist attractions. The cultural diversity must be packaged into tourism products, so the products can be sold and attractive for tourists.

There were various problems and obstacles in tourism development at Makassar City namely; limited facilities and tourism competitiveness, minimum tourism information, limited art and culture show, unprofessional tourism destination management, the lack of tourism certified human resources, the lack of tourism promotion, and security factors. Those problems and obstacles cause local income could not be improved and Makassar had no tourism attractions for tourists. 


\subsection{Problem Statement}

What is the determinant factors that influence the implementation of bureaucracy accountability in Public Administration of Tourism and creative economy Department, Makassar city?

\subsection{The Objective of the Research}

This research is to find and to analyze the determinant factors that influence the implementation of bureaucracy accountability in Public Administration of Tourism and creative economy Department, Makassar city.

\section{Review of Related Literature}

\subsection{Bureaucracy Accountability in Organization Perspectives}

Bureaucracy accountability in public organization is defined implicitly as public rights in understanding the policies of organization work program. In relation with the bureaucracy, accountability is the obligation to be responsible or answer and explain the performance by someone/law institution/organization leader to other parties who has rights to ask for information or responsibility. Accountability is also the foundation of the governance implementation processes. This is necessary because government officials accountable for actions and his work to the public and the organization of work.

Accountability as a fundamental requirement to prevent the misuse of delegated authority and guarantee authority is directed at achieving national goals. The goals are widely accepted by the level of efficiency, effectiveness, honesty and trust. Administratively, an organization needs strong hierarchical relationship between accountability centers and units. This hierarchical relationship is usually assigned clearly and properly in organization rules. The rules can be delivered in informal or formal network relationship. The accountability prioritized the upwards first, then the downwards. The supervision was done intensively, so the apparatus can follow the instructions properly. Carino (1993) and Enos (2013) explained that public accountability involves public institutions and bureaucracy to control different expectations that come from within and outside the organization.

\subsection{The Concept of Public Accountability}

Accountability can be defined as obligations from individuals or government that is trusted to manage the human resources to answer anything that is related to the accountability as instrument for control activity, especially in achieving the result of public administration. (Reynaldi and Nur, 2011). In terms of accounting, accountability is a situation where the financial statements are reported to the information user and can be responsible for the truth. It is intended that each of the accountability report should be in accordance with the rules of good and right accounting.

Meanwhile, according to Hendrikus (2007), Accountability is a situation where accounting is suitable with the real condition or accounting principles. Public accountability as moral responsibility assessment for actions and decisions is included into public expenditures. It is important to see indicators of accountability to measure whether or not the accountability is implemented. The indicators are transparency, accessibility, reporting standards, control (monitoring and evaluation), and responsibility. Betelli (2004, p. 11) said that accountabilities are those methods, procedures, and forces that determine what values will be reflected in the administrative decision.

According Ghartey (1987) accountability is intended to find answers from questions relating to the administration of what, who, whom, whose, where, and how. Meanwhile, according to Jabbra and Dwivedi (2003), the government should carry out thorough accountability to the public interest. Accountability is also an instrument for the control activities mainly in achieving results in the public administration.

\subsection{The Concept of Public Administration}

The public administration substances are always associated with activity by someone or groups or particular institutions to provide assistance and convenience to the public in order to achieve certain goals. The public service is very important because it is always in touch with people who have a wide range of interests and goals. Therefore, public service institutions can be done by the government or non-government.

Government is the bureaucracy organization of public administration. The government as bureaucratic organization is a leading organization dealing with public administration. In this case, the government institutions provide services, it is 
also essential to provide assistance and convenience to the public in order to fulfill their needs and interests. The whole qualified services are delivered to the community because the efforts of all employees, and not just of interest in the "front liners" only. According Lenvine (1990) said that the process of providing public administration must be suitable with the principles of correct or administrative provisions. The core of the public administration is the attitude of helpfulness, friendly and professional in providing services or products from an agency that satisfy the community and caused people to come back if the services of the institution are required.

Public administration is based on the theory that teaches the existence of an egalitarian democracy and equality among citizens (Denhardt and Denhardt, 2003). Public administration must be responsive to the interests and values that exist. Due to the dynamic nature of society, the character of the public administration must also be constantly changed following the development of society.

\subsection{The Concept of Tourism Administration}

World Tourism Organization (WTO) defines tourism as "activities of person traveling to and staying in places outside their usual environment for not more than one consecutive year for leisure, business and other purpose". Tourism is a very important part in development activities due to the activities of tourism can help the government in promoting economic growth. To increase the number of tourist visits, the government should do a lot of tourism promotion activities through exhibitions or art and culture performance on an ongoing basis both domestically and abroad with the communities and other travel businesses such as businesses in the creative economy. In order to provide the tourism professional services to the tourists, the government conducts human resource development through education and training activities. The government provides internship program from good Tourism Company so people can get a lot of experience and the tourists easily get information about tourism. The government provides information on each attraction as well as in other public areas by working with the media. The government also increases cooperation with the security forces to provide security for the tourists, so the tourists do not hesitate to visit a tourist attraction. Constitution No. 10, 2009, article 28 On Tourism said that the government should provide facilities that support tourism visiting. This would lead confidence in public and tourists to the government. To develop tourism infrastructure that is appropriate to the needs and competitiveness of travel, the government needs to cooperate with various parties.

\section{Research Method}

This research applied qualitative research with phenomenological approach. The technique of collecting data is conducted through observation, interviews, documents, online data searches and FGD.

The validity of the data was obtained through the validity instrument, according to Miles and Huberman (2005, p. 324) with a test that is; credibility, transferability, dependability and conformability.

The technique of data analysis was interactive analysis model of Miles and Huberman (2009). Data Reduction involves the electoral process, focusing on simplification, abstraction and transformation of raw data that emerged from the record field. Data Display involves a brief description, chart, relations between categories, and the presentation of narrative data. Verification and Data Collection is the data collection after withdrawal conclusions based on the issues and research purposes. In order to obtain propositions, statements or resume as the study's findings could be applied generally. Data Collection is made after the conclusion based on the issues and research purposes. In order to obtain propositions, statements or resume as research findings can be applied generally.

\section{Results and Discussion}

\subsection{The Determinant Factors Affecting Implementation of Bureaucratic Accountability in Public administration at the Office of Tourism and Creative Economy of Makassar}

\subsubsection{Professional}

The development of tourism as an integral part of the development, will be able to bring fresh air for development in a country. It is not independent of the government's efforts that continue to build the tourism sector became the sector that will be featured as the supporting pillars of the economy. To organize tourism, it is effective to apply professionalism. By having a professional tourism personnel, there will be an impression and a positive impact on the business activities of tourism. 
To get professional tourism personnel, education and training are important to do in stages and sustainably. The tourism staffs needs to be trained to fulfill the needs and competitiveness of tourism. Cooperation with educational institutions is also important by holding an internship program or a comparative study on the advanced countries in the field of the tourism, so the staffs can get experience in providing tourism services. This activity is counted on personnel who deal directly with tourists (Front Liner), because by having a professional force as expected in providing good service and at the maximum rating that will affect the number of tourist visits in Makassar. Besides, security needs to be increased, so the expectations of society or the tourists will be suitable. Good and qualified service will produce a good service anyway (Albrechte and Zemke, 1990) and constitution No. 10 of 2009, article 6 on Tourism said that the government should provide tourism services in accordance with human needs for traveling. Article 53 said that the workforce in the field of tourism must have a standard of competence.

Tourism activities in Makassar has been running as well as the expectations of society and the tourists. In this case, because not supported by professional human resources, the tourism is still lack in a special tourism certification. Load-intensive tasks are not supported the level of employee welfare and also tourism facilities and infrastructure are still inadequate or not in accordance with the needs and competitiveness of travel. There are also the deployment of staff that are not relevant to their expertise and the frequency of mutations or displacement apparatus.

\subsubsection{Trust}

Definition of services under the Act public administration is an activity or series of activities fulfillment services in accordance with the laws of every citizen and resident in the goods, services / or administrative services provided by the government as public administration providers. Service is the main task of the essentials of the apparatus figure as civil servants and public servant. Good and integrated public administration are to improve public confidence in the state apparatus.

The development of the tourism sector as one of the potential sectors is expected to have a real contribution. As the host, Makassar government should be able to provide comfort in an individual, group, guests from within and outside the country, this means with a friendly service and wholeheartedly, other guests are interested to visit. One thing that is lately in question is in the field of public administration (Public Service), especially in terms of quality or the service quality to the community of the government apparatus. Government as service providers for the public are required to provide a qualified service. Denhardt and Denhardt (2003) said serving the community in a democratic, equitable, no discrimination, honest and accountable way. Especially in the era of regional autonomy, the quality of service of government officials will be increasingly challenged to optimal and able to answer the higher demands from public. Thus, it is important to give a positive impression and to build public trust in various fields, especially in the field of tourism.

In developing countries, it can be seen that the quality of public administration is a problem that often arises. As in many developing countries, the demand for services far exceeds the ability of the government to fulfill, so that the services provided by the government to the poor is fulfilled in terms of quality and quantity. (Service Quality, Zeithaml, Parasuraman and Berry, 1990)

To create public trust in high regard to the tourism ministry, the government should provide a good and qualified service, provides the right information to the travel destination (Article 20 of Law No. 10 of 2009 about Tourism). The government also provides facilities and infrastructure according to the needs and competitiveness travel, provides a means of accessible information by the tourists, and provides safety for the tourists as well as creating a conducive investment climate. Thus, the businesses and tourism actors will invest in the field of tourism in Makassar by making facilities and infrastructure are in accordance with the needs and power travel competitiveness can be fulfilled.

\subsubsection{Cooperation}

Partnership and cooperation between the central government and local governments, between governments, private and public, state / enterprises, mass media, educational institutions and organizations International tourism is indispensable in encouraging tourism development goals. Law No. 10 of 2009 about Tourism, Article 17 said that the government must establish a partnership with micro, small, medium and cooperative efforts in the field of tourism. Article 28 said that the government's authority is to organize international cooperation in the field of tourism in accordance with the provisions of the legislation. Government's role in providing infrastructure and regulatory framework to encourage private and public sectors actively participate in tourism activities. Thus, the efforts to develop patterns of partnership and cooperation are effective and efficient in order to support the development of tourism. The cooperation needs to be developed and improved according to the needs and tourism competitiveness. 
Development of tourism is one of the potential sectors that need to be developed, it is appropriate statement that

"Tourism can be a potent development tool, generating economic growth, diversifying the economy, contributing to poverty alleviation and also creating backward and forward linkages to other production and service sectors." (lain T. Christie and D. Elizabeth Crompton, 2003, p.63).

The development of the tourism industry is certainly involves many sectors that have an interest respectively, both from the government, the public, the media, educational institutions and the business world with all the motivation and purpose. Developing and promoting partnership cooperation in various areas is one way to mutually reinforce and improve competitiveness. The basic principle of partnership carries equality, transparency, formal and legal, mutually reinforcing, mutual understanding, mutual benefit, transfer of knowledge and experience, exchange of information, and institutional. The model of tourism business partnerships benefits all stakeholders, both at the level of policy and operational implementation. The partnerships model should be presented to the public to create transparency in government

\subsubsection{Facility}

The availability of accessibility, multimedia network and connectivity to tourist destinations is one of the factors that determine the quality of the development of tourist destinations. Tourism accessibilities are all kinds of transportation facilities and infrastructure that supports the movement of tourists from the origin region to tourism destination and the movement in the area of tourism destinations in terms of motivation excursions. The tourism sector is largely determined by the ease of mobility and infrastructure. Tourists would prefer if the regions they visited have accessible mobility and have comfortable infrastructure as their own country (Mo, Howard, and Hivitz, 1993).

More specifically, transportation infrastructure can create a local travel sector growth because of connectivity between origin regions and destination (Kaul 1995 and Prideaux 2000). A number of empirical studies show that the availability of infrastructure is a major determinant in attracting tourists (Gearing et al, 1974; Mc Elroy, 2003; Soetinah et $\mathrm{al}, 2011)$. Establishing facilities and infrastructure for tourism is not as easy as turning back hands. There is a challenge such as the availability of a limited budget and also problematic land for tourism activities.

To provide facilities and modern tourism infrastructure that suits with needs and tourism competitiveness such as transportation infrastructure, and Information and Technology (IT, wifi). Governments should also cooperate with various parties such as the central government, local governments and private surrounding. Law No. 10 of 2009 about Tourism, Article 1 paragraph 3 said that tourism is a wide range of tourist activities and supported a variety of facilities and services provided by governments, communities, businesses and local governments. The government only provides regulation while others provide facilities. The form of cooperation should be presented to the public in order to create transparency in government.

\section{Conclusion}

Accountability is a measure to show whether or not public bureaucracy or administration by government is suitable with the values and norms in society and whether or not the public administration can accommodate the society needs for real. To get accountable tourism administration, it is necessary professional human resources. To create public trust, it is necessary to give good service. It is necessary to get accessible information about tourism and to guarantee the tourists' security. The last is to create good cooperation with other parties and to provide facilities based on needs and tourism competitiveness.

\section{References}

Burke, John P. (1986). Bureaucratic Responsibility. Baltimore, MD: John Hopkins Institute for Development Studies. Caiden, G.E. (1991). Administrative Reform Comes of Ages. New York: De Gruyter.

Carino, L.V. (1991). Accountability, Corruption and Democracy. Manila: Philippines Istitute for Development Studies. Carison, Dick. (1981). Modern Management: Principles and Practice (translated by Ny A Yasin) USA: OECED

Creswell, JW. (2002). Research Design Qualitative and Quantitative approaches, Trasnlated by Nur Khabibah. Jakarta: KIK press.

Denhardt, Robert B., \& Janet V, Denhardt. (2003). The New Public service - Serving, not steering. Expanded edition, London: M.E. Sharp.

Eko, Nurmianto et al. (2004). Perumusan Strategi Kemitraan Menggunakan Metode AHP dan SWOT (Studi Kasus pada Kemitraan PT. INKA dengan Industri Kecil Menengah di Wilayah Karesidenan Madiun). Jurnal Teknik Industri, Vol. 6, No. 1, June 2004.

Francis Butle. (1996). "Relationship Marketing Theory and Practice", British Library Cataloguing in Publication Data London: Paul 
Chapman Publishing Ltd.

Fulmer, R.M. (1984). The New Management. New York: Mc.Millan Publishing Co. Inc

Hardiyansyah. (2011). Kualitas Pelayanan Publik. Yogyakarta: Gava Media.

Hendrikus. (2007). Akuntabilitas Kelembagaan Eksekutif. Jurnal IImu Administrasi Publik, Vol. 4, No. 1, Maret 2007.

Henry, Nicolas. (1980). Public Administration: A Comparative Perspective. New Jersey: Presentice Hall. Inc

Anonim. (1995). Administrasi Negara dan Masalah-masalah public. Jakarta: Raja Grafindo Persada.

Honey, Martha. (1999). Ecotourism and Sustainable Development (Who Own Paradise). Washington DC: Island Press.

Hui Liao., \& Chuang, Achia. (2004). A Multilevel Investigation Of Factors Influencing Employee Service Performance and Customer Outcomes. Academy of Management Journal, Vol. 47, No. 1, pp. 41-58.

Hughes, O. (1994). Public Management and Administration: An Introduction. New York: St Martin Press.

Ibrahim, A. (2009). Pokok-pokok Administrasi public dan implementasinya. Bandung: PT. Refika Aditama.

Joseph Jabbra., \& Dwivei. (1989). Public Service Accountability: A Comparative Perspective. Kumarian Press.inc

Helliwell, John F. (2005). Well-Being, Social Capital and Public Policy: What's New?. Nation al Bureau of Economic Research 2005.

Miles, Matthew B., \& Huberman, A Michael. (1992). Analisis Data Kualitatif, Buku Sumber Tentang Metode-Metode baru, Translated by Tjetjep Rohendi Rohidi. Jakarta: Universitas Indonesia.

Mill Christie Robert. (1996). Tourism The International Business. Jakarta: PT. Raja Grafindo Persada.

Nurhayati, Windue., \& Hwang W.G (2002). Private and Public Sector Partnership in Tourism Development. Yogyakarta: Gaja Mada University Press.

Pangestu, Mari Elka., \& Nirwandar, Sapta. (2012). Pengembangan Pariwisata dan Ekonomi Kreatif di Indonesia. Jakarta: PT. Gramedia Pustaka.

Philip, Kotler. (2002). Marketing Management, Millennium Edition. University of Phoenix: Pearson Custom Publishing 2002.

Rakhmat. 2004. Akuntabilitas Birokrasi Pemerintah Daerah dalam Penyelenggaraan Pelayanan Publik di Kota Makassar. Dissertation. Makassar: Universitas Hasanuddin Makassar.

Ratminto., \& Winarsih, Atik Septi. (2006). Manajemen Pelayanan: Pengembangan Model Konseptual, Penerapan Citizen's Charter, dan Standar Pelayanan Minimal. Yogyakarta: Pustaka Pelajar.

Ratminto, et. al. (2007). Manajemen Pelayanan. Yogyakarta: Pustaka Pelajar.

R.C. Chandler., \& J.C Piano. (2008). The Public Administration Dictionary, $2^{\text {nd }}$ ed. Santa Barbara: ABC-CLIO Press.

Steband, Jeffrey., \& Jones, Malic. (2012). How to Managed of Tourism Organization Efectiveness. New Jersey: Prentice Hall.

Tjiptono Fandy., \& Chandra, Gregorious. (2007). Service Quality \& Satisfaction. (Edisi 2). Yogyakarta: Andi.

Tjokroamidjojo, Bintoro. (2000). Good Governance, Paradigma Baru Manajemen Pembangunan. Jakarta: UI Press.

Tyler, Duncan Tyler. (1998). Managing Tourism in Cities (Policy, Process and Practice). England: British Library Cataloguing.

Widodo, Joko. (2001). Good Governance- Telaah dari Dimensi: akuntabilitas dan Kontrol Birokrasi pada Era Desentralisasi dan Otonomi Daerah. Surabaya: Insan Cendekia.

Wiendu, N. (2000). Principles of Tourism. Australia: Longman. 